\title{
THE EFFECTIVENESS OF DONALD SUPER CAREER COUNSELING IN INCREASING STUDENT SELF EFFICACY AND CAREER COMMITMENT
}

\author{
Asfarina Mutiara*, Budi Astuti \\ *Correspondent Author
}

Asfarina Mutiara

Universitas Negeri Yogyakarta

Jalan Colombo Nomor 1, Sleman,

Yogyakarta

Indonesia

Email :

asfarinamutiara.2019@student.uny.ac.id

Budi Astuti

Universitas Negeri Yogyakarta

Jalan Colombo Nomor 1, Sleman,

Yogyakarta

Indonesia

Email : budi_astuti@uny.ac.id

Page

58-63

\begin{abstract}
The study aims to determine the effectiveness of Donald Super's career counseling in increasing student self-efficacy and career commitment. This experimental research involved 20 guidance and counseling department students in the Special Region of Yogyakarta, Indonesia, recruited using purposive sampling technique. The subjects were divided into two groups. Self-efficacy and career commitment scales were deployed to collect the data. The collected data were analyzed using Wilcoxon test. The results of the study show that Donald Super's career counseling was effective in increasing self-efficacy and career commitment of guidance and counseling students. The results of this study can be used as a reference by counselors in higher education to increase self-efficacy and career commitment of students using Donald Super's career counseling.

Keywords: self efficacy, career commitment, career counseling, donald super
\end{abstract}

\section{INTRODUCTION}

Career is an important aspect of an individual's development related to work and position, among others. It serves as one's life journey instead of a goal. It is viewed as a series of individuals' life-long behaviors related to work experiences and activities (Pratama \& Suharman, 2014; Agungbudiprabowo, et al., 2019; Jiang, et al., 2019).
Career planning and decision-making activities are challenging as they are timeconsuming processes. Individuals with good self-efficacy are likely to make the right career choice and be responsible for their choice by exhibiting a high commitment. Bandura defines self-efficacy as individuals' belief in their ability to control their function and events in their surroundings (Pal, et al., 2018; Schiele, et al., 2016; Joët, et al., 2011). 


\section{9| PSIKOPEDAGOGIA}

JURNAL BIMBINGAN DAN KONSELING

Vol.10, No.2, December 2021

Individuals should be able to tackle their career problems to develop properly. Career problems can occur anytime, not only in the planning and decision-making process. Thus one's self-confidence and commitment to success can play decisive roles in determining one's career success.

Career problems are also experienced by guidance and counseling students in the Special Region of Yogyakarta, Indonesia. Self-efficacy is an important component in individual career development as it is positively associated with career development. However, the facts show that many guidance and counseling students still fail to realize their potential and are uncertain of their capacities, causing them to fail to plan their careers appropriately.

In addition to low self-efficacy, guidance and counseling students in the Special Region of Yogyakarta were also found to have low career commitment, indicated by their lack of understanding of their personality and work.

This condition requires immediate responses as failure to properly address this issue can be detrimental to their career development. One of the counseling services, i.e., Donald Super's career counseling, can potentially handle this issue.

Donald Super's career theory describes three key aspects of career development: a) life span, b) life space, and c) self-concept (Niles \& Bowlsbey, 2016; Budiman, et al., 2020). Previous studies have reported successful implementation of Donald Super's theory in improving a range of individual career development aspects. One of the studies were conducted by Robbaniyah, et al. (2013), reporting that career counseling with Donald Super's theory manages to improve the career adaptability among guidance and counseling students. Another research by Redita et al. (2014) concludes that the application of Super career counseling with audio-visual-assisted modeling techniques can improve the career attitudes of 11 th-grade students in the accounting program at SMK $\mathrm{N}$ 1 Singaraja.

Grounded on the previous studies on this topic, the present study aims to test the effectiveness of Donald Super's career counseling in increasing self-efficacy and career commitment among Guidance and Counseling department students. Selfefficacy and career commitment were chosen because many schools still lack school counselors to handle this issue. This study is expected to improve students' self-efficacy and career commitment as prospective school counselors. Studies on self-efficacy and career commitment have been conducted in many contexts, yet works involving guidance and counseling department have never been reported. The results of this study can be used as a reference by university counselors to improve student self-efficacy and career commitment using Donald Super career counseling.

\section{RESEARCH METHOD}

This experimental study involved twenty guidance and counseling department students in the Special Region of Yogyakarta, Indonesia. They were recruited using purposive sampling technique. The data were collected using a career self-efficacy scale and a career commitment scale and analyzed using Wilcoxon test.

\section{RESULT AND DISCUSSIONS}

In this study, 20 guidance and counseling department students were assigned into two groups of ten, the experimental control groups. The experimental group was treated using Donald Super career counseling to increase self-efficacy and career commitment. Meanwhile, the control group was treated using other counseling techniques. The comparison between the pretest and posttest results and increased self-efficacy and career commitment is presented in Table 1.

Table 1

Pretest-Posttest Score Comparison

\begin{tabular}{lcccc}
\hline & \multicolumn{2}{c}{ Experimental Group } & \multicolumn{2}{c}{ Control Group } \\
& Pretest & Posttest & Pretest & Posttest \\
\hline Total score & 1340 & 1455 & 1430 & 1504 \\
Median & 137 & 144 & 145 & 143 \\
Max. & 147 & 172 & 147 & 174 \\
Score & & & & \\
Min. Score & 114 & 132 & 137 & 136 \\
Mean & 134 & 146 & 143 & 150 \\
Category & $\begin{array}{l}\text { Moderate } \\
\text { improved }\end{array}$ & $\begin{array}{c}\text { Moderate } \\
\text { Description }\end{array}$ & \multicolumn{2}{c}{$\begin{array}{c}\text { Moderate } \\
\text { Improved }\end{array}$} \\
\hline
\end{tabular}


The hypotheses of the study were tested usingWilcoxon signed rank test, which result is presented in table 2 .

Table 2

Wilcoxon Test Result

\begin{tabular}{cccc}
\hline $\begin{array}{c}\text { Wilcoxon } \\
\text { Test }\end{array}$ & $\begin{array}{c}\text { Significance } \\
\text { value }\end{array}$ & $\begin{array}{c}\text { null } \\
\text { hypothesis }\end{array}$ & Conclusion \\
\hline $\begin{array}{c}\text { Experimental } \\
\text { and control }\end{array}$ & $0,007<$ & rejected & there is a \\
group & 0,05 & & difference \\
pretest & & & \\
Experimental & $0,012<$ & rejected & there is a \\
and control & 0,05 & & difference \\
group & & & \\
pretest- & & & \\
posttest & & Accepted & no \\
Control & $0,444>$ & & difference \\
group & 0,05 & & no \\
Pretest- & & Accepted & difference \\
posttest & & & \\
Experimental & $0,799>$ & & \\
and control & 0,05 & & \\
group & & & \\
Posttest & & & \\
\hline
\end{tabular}

As presented in Table 2, the experimental group pretest-posttest data has different data variants with a probability value of 0.012 $<0.05$, the null hypothesis $(\mathrm{Ho})$ is rejected, which means that there is a significant difference in the level of self-efficacy and career commitment of students before and after being given treatment. While the pretest-posttest data acquisition of the control group has a probability value of $0.444>0.05$, the null hypothesis $(\mathrm{Ho})$ is accepted, which means that there is no significant difference in the level of self-efficacy and career commitment of students in the pretest and posttest of the control group. Therefore, it can be concluded that Donald Super's career counseling is effective in increasing selfefficacy and career commitment of guidance and counseling students.

The results of the research based on the hypothesis test showed that Donald Super's career counseling was proven to be effective in increasing self-efficacy and career commitment of guidance and counseling students. These results support previous research (Fitriyani, Handayani et al, 2019) on the implementation of Donald Super's theory in career guidance service programs. The research resulted in a career guidance program to prepare, introduce, and provide information to individuals about fields of study and careers. The career guidance program produced contains various types of services such as orientation services, information, group guidance, classical guidance, and counseling.

Self concept theory is a very important part of Super's approach to vocational behavior (Putra, 2021). Vocational self concept develops through physical and mental growth, observation of work life, identifying working adults, general environment, and experiences in general. Based on the theory put forward by Super, every individual has his potential so that someone who has the skills and talents will be able to complete various tasks. The development of self-concept goes hand in hand with the development of individual selfefficacy, both of which have some similarities and can predict motivation, emotion, and performance to some extent. Furthermore, self-efficacy is one of the factors of career commitment, so it can be said that the higher the self-efficacy, the higher the individual's career commitment. And vice versa when someone does not have a good self-concept referring to low self-efficacy, it will be difficult to increase self-potential and difficult to bring up high career commitment.

Based on the results of studies conducted, it is stated that Donald Super's career theory is effective in increasing student self-efficacy and career commitment, besides Donald Super's career theory has also been proven to be effective for increasing vocational students' work readiness (Mutmainah \& Arumsari, 2020). Through this study, it can be concluded that Donald Super's career theory can improve the job readiness of vocational students so that at the tertiary level individuals have work readiness that leads to a high level of self-efficacy and commitment so that individuals will live their careers well.

Career planning is carried out by individuals starting from elementary school until finally they can make career decisions. Through good career planning, it can be predicted that individuals will be able to make career decisions. However, it is undeniable that in carrying out these career decisions there will be many factors that make individuals may waver with their choices. This 


\section{1| PSIKOPEDAGOGIA}

JURNAL BIMBINGAN DAN KONSELING

Vol.10, No.2, December 2021

can be a problem and an obstacle for individuals in their career development.

Super (Mansyur, et al., 2019; Nurrillah, 2017) explains that students at the age of 1825 years have reached the stage of specification and implementation of preferences in work. Characteristics of career development of adolescents or early adults who are at the exploration stage are marked by starting to conduct self-study, try to divide various roles, and explore jobs or positions. To achieve career success in the world of work, self-confidence and commitment are needed in a career.

Career commitment is an attitude towards a profession or job (vocation) which includes the development of personal career goals and identification and involvement in these goals (Ingarianti \& Purwono, 2019; Febriansah, 2019). Meanwhile, according to Vandenberghe \& Ok (2013), career commitment is a person's attitude in achieving goals for self-development that reflects one's commitment to personal goals.

Individuals with high career commitment and self-efficacy tend to have higher salary and career satisfaction. Alzyoud (2017) found that career commitment, career value, and organizational support have a positive and significant relationship with career success. Research conducted by Ingarianti (2017) shows that career commitment is influenced by internal factors and external factors. Internal factors consist of organizational commitment, job involvement, job satisfaction, work values, work experience, personality, and self-efficacy. The higher the self-efficacy, the higher the individual's career commitment. Career commitment and self-efficacy need to be increased in order to increase career success as well. Therefore, in this study, treatment was carried out to assist individuals in increasing career commitment and selfefficacy through Donald Super's career counseling.

The goal in Donald Super's career counseling refers to the stage of career development, which is to help students explore by thinking about various career alternatives that will be pursued. The advantage of career counseling using this
Super theory lies in the individual's ability to realize the self-concept in a field of office that is most desirable for self-expression and is also related to the choice of the role they have. The embodiment of this self-concept has a correlation with self-efficacy, where both have some similarities and can predict motivation, emotion, and performance to some extent. It was further explained that the relationship between self-concept and self-efficacy is something that can happen because beliefs about self-efficacy will build a cognitive foundation to form a self-concept. Self efficacy is also a factor of career commitment where career commitment applies as a determinant of one's success. So it can be said that the higher the self-efficacy, the higher the career commitment. On the other hand, when a person does not have a self-concept which refers to poor self-efficacy, it will be difficult to manifest himself in a field and lead to high career commitment.

Awareness of the importance of selfefficacy and individual career commitment in the process of undergoing a career has appeared in the delivery of counselees in the career counseling process, this will help individuals increase their career potential. Through the pretest-posttest, students have shown a significant improvement, but there are still students who have not achieved optimal improvement so of course they still need guidance, maintenance, and selfefficacy development and career commitment. Guidance and counseling service centers and support systems play an important role in increasing student selfefficacy and career commitment in a higher education environment. Thus, Donald Super's career counseling service can be an alternative in helping students solve career problems related to self-efficacy and career commitment so that in the end students are able to develop their potential.

\section{CONCLUSION}

Based on the results of the study, it can be concluded that Donald Super's career counseling is effective in increasing selfefficacy and career commitment of guidance and counseling students. The results of this 
study can be used as a reference by counselors in higher education to improve student self-efficacy and career commitment using Donald Super career counseling.

\section{REFERENCE}

Agungbudiprabowo, S., Widyastuti, D. A., \& Muyana, S. (2019). College Students' Career Planning Ability.

Alzyoud, A. A. Y. (2017). The Predictors Of Career Success. International Review of Management and Marketing, 7(2), 22-26.

Budiman, C., Gunawan, G., \& Hidayat, D. R. (2020). Layanan Bimbingan Karir Teori Donal E. Super Guna Meningkatkan Kematangan Karir Pada Peserta Didik Di Sekolah Menengah Kejuruan (SMK). Jurnal Ilmiah Bimbingan Konseling Undiksha, 11(1).

Febriansah, R. E. (2019). Pengaruh Perencanaan Karir Terhadap Komitmen Karir dan Kepuasan Karir melalui Pengembangan Karir sebagai Variabel Intervening. JBMP (Jurnal Bisnis, Manajemen dan Perbankan), 5(1), 8-14.

Fitriyani, N., Handayani, R., Putri, D. T., \& Hidayat, D. R. (2019). Implementasi Teori Donald E. Super pada Program Pelayanan Bimbingan Karir untuk Siswa Sekolah Menengah Pertama. Ilmu dan Budaya, 41(65).

Ingarianti, T. M. (2017). Faktor-Faktor yang Mempengaruhi Komitmen Karier. Jurnal IImiah Psikologi Terapan, 5(2), 202-209.

Ingarianti, T. M., \& Purwono, U. (2019). Adaptasi Instrumen Komitmen Karier. Jurnal Psikologi Undip, 18(2), 199-217.

Jiang, Z., Newman, A., Le, H., Presbitero, A., \& Zheng, C. (2019). Career Exploration: A Review and Future Research Agenda. Journal of Vocational Behavior, 110, 338-356.

Joët, G., Usher, E. L., \& Bressoux, P. (2011). Sources Of Self-Efficacy: An Investigation Of Elementary School Students In France. Journal of Educational Psychology, 103(3), 649.

Mansyur, A. I., Chairunnisa, D., \& Hidayat, D. R. (2019). Implementasi Teori Super pada Program Layanan Bimbingan dan Konseling Karir untuk Mahasiswa Perguruan Tinggi. Psikologi Konseling, 15(2).
Mutmainah, N., \& Arumsari, C. (2020). Efektivitas Layanan Informasi Karier Menggunakan Teori Donald. E. Super untuk Meningkatkan Kesiapan Kerja Siswa. QUANTA, 4(3), 114-125.

Niles, S. G. \& Bowlsbey, J. H. 2016. Career Development Interventions. Library of Congress Cataloging-in-Publication Data.

Nurrillah, S. L. (2017). Program Bimbingan Karir untuk Meningkatkan Kematangan Karir Mahasiswa. Journal of Innovative Counseling: Theory, Practice, and Research, 1(01).

Pal, N. E., Gumuchian, S. T., Delisle, V. C., Pépin, M., Malcarne, V. L., Carrier, M. E., ... \& Scleroderma Support Group Project Advisory Team*. (2018). Development and Preliminary Validation of The Scleroderma Support Group Leader Self-Efficacy Scale. Journal of Scleroderma and Related Disorders, 3(1), 106-111.

Pratama, B. D., \& Suharnan, S. (2014). Hubungan Antara Konsep Diri Dan Internal Locus Of Control Dengan Kematangan Karir Siswa SMA. Persona: Jurnal Psikologi Indonesia, 3(03).

Putra, B. J. (2021). Studi Literatur: Teori Perkembangan Karir Donald Edwin Super. Coution: Journal of Counseling and Education, 2(1), 22-30.

Redita, I. K., Suranata, K., \& Dharsana, I. K. (2014). Penerapan Konseling Karir Super Tehnik Modeling Berbantuan Audio Visual untuk Meningkatkan Sikap Karir Siswa Kelas XI Akuntasi D Smk N 1 Singaraja Tahun 2013/2014. Jurnal IImiah Bimbingan Konseling Undiksha, 2(1).

Robbaniyah, N. I., Mamesah, M., \& Fitri, S. (2013). Efektivitas Layanan Konseling Karir untuk Meningkatkan Kemampuan Adaptasi Karir Mahasiswa BK FIP UNJ Angkatan 2011. INSIGHT: Jurnal Bimbingan Konseling, 2(2), 76-80.

Schiele, M. A., Ziegler, C., Holitschke, K., Schartner, C., Schmidt, B., Weber, H., ... \& Domschke, K. (2016). Influence of 5-HTT Variation, Childhood Trauma And Self-Efficacy on Anxiety Traits: A Gene-Environment-Coping Interaction Study. Journal of Neural Transmission, 123(8), 895-904.

Vandenberghe, C., \& Ok, A. B. (2013). Career Commitment, Proactive Personality, And Work Outcomes: A Cross-Lagged 
63 | PSIKOPEDAGOGIA

JURNAL BIMBINGAN DAN KONSELING

Vol.10, No.2, December 2021

Study. Career Development

International. 